\title{
Erzya chastushka - vanishing or changing oral tradition?
}

\section{Introduction}

Concise, apposite and quick-witted texts and tunes are the bread of modern popular music and hits that display numerous variants of short and pithy performances. The traditional folklore genres and oral tradition of Finno-Ugric peoples have not had such characteristics. On the contrary, reports on traditional oral poetry have documented epic genres and long, narrative forms of folklore. The changes that took place during the $20^{\text {th }}$ century in the language and culture of Finno-Ugric communities brought a considerable change in oral tradition as well. Chastushkas, an originally Russian genre, brief and mainly humoristic songs entered the folklore of many Finno-Ugric peoples. Generally speaking, they fulfill all the typical criteria of a folklore genre. They are merely oral songs that are never distributed in a printed form, nor are they in mass media and, as a rule, they are typically only impromptu.

The current paper presents a short overview and selection of Erzya chastushkas that were recorded in Erzya villages during expeditions that were made in the 1990's. Chastushkas are known from the $20^{\text {th }}$ century folklore tradition of other Finno-Ugric peoples living in the European part of Russia as well and the first examples were published before the Second World War. Language is the most relevant characteristic that distinguishes Erzya chastushkas from Russian, Karelian, Veps, Mari, Udmurt and Komi chastushkas or those of any other people. Like numerous other ethnic minorities in Russia these Finno-Ugric peoples have learned this aphoristic and humoristic genre from the Russians. Given the parallel tradition in many cultures, the adaption to local folklore tradition takes place by means of language.

Although the title Erzya chastushka - vanishing or changing oral tradition? posits a question the paper is not meant to answer it. Instead of it our goal is to point out that despite considerable changes that took place in Erzya cultural traditions and Erzya-speaking communities during the $20^{\text {th }}$ century chastushkas are an example of a living tradition that appeared in Erzya culture at a period in which traditional forms of oral tradition were lost. This claim is evidenced in the data and the sample that is far from an exhaustive collection. In fact, given the dynamic and productive character of this genre it would not make much sense to handle the issue as an object within a quantitative frame.

The publishing of the following data thus serves three aims. Firstly, it introduces a modern form of oral tradition that historically, in a way, fills the gap of several lost genres. Secondly, it presents chastushkas as a genre that was originally adopted from Russian culture but was transferred to the Erzya as it did among other groups. Thirdly, it seeks to promote the interest of folklorists towards living tradition of Finno-Ugric peoples. 


\section{The historical background of chastushkas as an oral genre}

Unlike traditional folklore forms of agrarian and nomadic communities, the chastushka is an undeniable newcomer in the list of various forms of oral tradition. It developed during the second half of the $18^{\text {th }}$ century in Russia and the name chastushka refers to the transient character of the performance (Russian частушка [cf. yacmbiŭ 'often' < * čęstъ] originally '[something that is] frequently repeated' [Vasmer \& Trubachev 1964-1973: 4: 318]). In the beginning love was the prevailing theme that gradually began to extend to other topics. The genre is not as typically improvised as some others, e.g. laments. Nor is it an undistinguishable part of any social rite or social ceremonies such as weddings that do not determine how, when or where chastushkas are performed. Later, chastushkas have gained popularity as an easily transformable genre that used to be accompanied with the accordion or balalaika and began to spread. During the expeditions from which the data below originates some of the informants even noted that earlier there had not been any chastushkas.

The oldest reports of Mordvin chastushkas date back to as early as the 1890's and are documented in the manuscripts of M. Ye. Yevsev'yev that include written chastushka texts (Samoshkin 1976: 6). The folklore collections of Heikki Paasonen originating from the same era include songs that are characterized as dance melodies (Mordwinische Volksdichtung 4 [1948]: 424-429), but they do not correspond structurally nor thematically to chastushkas. Conceivably, the chastushkas most probably were not widespread in Mordvin communities in the end of $19^{\text {th }}$ century (Samoshkin 1976: 41-45).

There are big differences between the chastushkas and traditional forms of Erzya oral folklore. Epic songs, bride songs, recruit songs and keens (wailing lament for the dead) were characteristic of old oral poetry and they had a very close liaison to social ceremonies and rites. The ceremonies themselves could last for several hours or even days and the forms of folklore corresponded to their social function also in time and duration (Mordwinische Volksdichtung, PMNMI, Saarinen 1990: 36-119, UPTMN) The epic songs were not strictly bound with time and space which is a feature mutually shared with chastushkas in some respect. However, it is evident that there is no natural way to combine any traditional Mordvin folklore genre with chastushkas in terms of continuity of folklore. Although the same performers and elder people who know chastushkas sometimes know some fragments of older genres there is hardly any inter-genre or cross-genre influence to be marked in Erzya chastushkas. The reason is evident, because old oral poetry has its roots in the past and extensive agrarian societies whereas chastushkas originate from Russian folklore and were implanted in the changing community. Yet, there is some evidence that old forms of Mordvinic oral tradition and folklore genres were adapted to a new social and political system during the intensive construction of a social society as organized local choirs began to perform them (MNP).

Interestingly, the chastushkas show up in the folklore of Erzya and other minority communities at the same time when more traditional forms were gradually aban- 
doned. The implementation of Soviet culture and model of a Soviet society by force contributed to a relatively rapid loss of oral tradition especially from the 1920's and 1930 's on as collective meetings such as village feasts were prohibited. After a famine that hit the Volga area in the beginning of 1920's and a relatively calm period in the mid 1920's troubles resumed with a forced collectivization of agriculture (Lallukka 1990: 64-69). Therefore, the appearance of chastushkas as an entirely new and admissible form that belonged to another cultural context obviously took over the role of older forms as the contents of musical performances. This, too, shows the ambiguity of chastushkas as a part of oral tradition. Although they are not ritual songs and foster improvisation, they have a clear social function. This hypothesis would deserve a more extensive discussion than will be done here.

Although intensive field work is currently carried out on various Finno-Ugric traditions, there are no up-to-date studies on the cultural and social role of the chastushkas. As a rule, the existing works such as UPTMN, MECh and SM that were published in Russia (see references below) are compilations of field data in a literary form.

Unfortunately, no Russian chastushkas and comparative data was recorded from the same informants. By the time the songs were transliterated and the introduction was written I realized that it would have made sense to record Russian chastushkas presented by the same informants that practically all were bilingual to at least some extent as all Erzyas currently are. However, the informants emphasized that Erzya chastushkas are unique and never translations from Russian chastushkas and, thus, basically more independent than one would assume of a bicultural tradition.

This partly contradicts the earlier observation of Samoshkin who assumes that a part of the Mordvin chastushkas is translated from Russian. There is no concrete documentation on the diffusion of Russian chastushkas in Mordvin areas but Samoshkin (1965: 402; 1976: 54), nevertheless, assumes that the adoption of Russian chastushkas in Mordvin-speaking communities took place by means of areal diffusion in the Oblasts of Penza, Gorkiy (Nizhniy Novgorod), Kuibyshev (Samara) and Voronezh. There are certain thematic types that are represented both in Mordvin and Russian chastushkas. However, Samoshkin (1965: 405) concludes that the number of translated chastushkas is not high, because the transferring of this genre is complicated.

\section{Thematic focus and variation}

The key characteristics of the chastushkas as a folklore genre do not focus on repeating a particular theme that would attach to social traditions and habits. The brevity and aphoristic clauses rather make the impression that the thematics is not as important as the chastushkas as the mediator of a social performance. As structurally short and momentaneous presentations they seem to fulfill in a way the same task as modern short folklore genres as anecdotes and jokes or traditions of children's communities that are a flexible and quite pertinent piece of European and American urban tradition (Lehtipuro 1980: 9). 
The reproduction rules of chastushkas are closely connected to the present-day world but contextual factors do not influence their performance very strictly. The genre itself is exclusively humorous and, hence, funerals and serious events are not the social environment where chastushkas are performed. Any occasion may stimulate people to start singing. An opposing attitude to seriousness and grave everyday matters is especially provocative.

Despite the thematic divergence, some motives are repeated more frequently than others. In the chastushka sample below, for instance, the introduction verga l'ivt'i eroplan 'above, there is an aeroplane flying', and its variants are repeated several times (cf. chastushkas [17, 18, 27, 43, 44]). A similar thematic reference is found in Tver Karelian chastushkas as well: timoškina šuuri külä, ieroplanat lennelläh 'Timoshkina is a big village, aeroplanes are flying' (Kukk 1989: 50). In this type of frequently reproduced motives one can assume that subtexts and Russian chastushkas are involved in the frequency and reproduction of the same motive. On the other hand, however, variation and a versatile multiplication of versions is a characteristic feature of oral tradition and cannot be separated from the old Erzya Mordvin epic song tradition either. There are also motives that are bound more tightly to the local language by means of rhymes, such as in chastushkas (19) and (33) (see below) or place names as Kosogor in chastushka (35) and Kuchan' (Kučań) in chastushka (39).

In general, chastushkas do not reveal much of old and aged historical and political changes in Erzya or Russian society. Instead of reflecting time they are a mirror of the performing situation and its world. This fits the assumption that reproduction is mostly limited to relatively short periods of time (Honko 1980: 24). However, those politicians and political issues that were pertinent in the given context and close to the time when the chastushkas were performed present a very sharp and satiric attitude. In chastushkas (50) and (57), for instance, Gorbachev and Yeltsin are made responsible for a miserable state of the subject of the chastushkas. Likewise, in chastushkas (18) and (51) perestroika is presented as a parallel to poverty and starving, the result of a political and social reform that Gorbachev had started only a few years earlier.

Environment and context do not play a very significant role in performing chastushkas although one would exaggerate by claiming that they have no role at all. The text outlines the contemporary world of the performer and the songs are tightly connected with social phenomena, of which love and social relationships are frequently repeated. Therefore, the context of the performance and humorous atmosphere without exited emotions is often more decisive for the chastushkas as the texts themselves. As other folkloristic texts chastushkas confirm that texts appear as a part of communication and they are based on direct contact between two or more people, in which the narrator himself has only a minor role. Of the different contexts listed by Hoppál (1980: 115-119) social is the most important, whereas e.g. linguistic context has hardly any significance. The narrator rejects the reference of the chastushka to the real world background and the theme of the chastushka culminates in one way or another in a comic thematic conflict that is often emphasized with rhymes. Language as such and as a mean of communication and social environment is more important than the linguistic environment. 


\section{Language and metrics}

Local language, dialects and variants are typically present in chastushkas that is characteristic of oral poetry and folklore. Although different singers would repeat the same motives as mentioned above, language and local forms and variants increase variation as kovont'e - lovont'e 'to the moon - to the snow' in chastushka number (19), but koyst'en - loyst'eń id. in chastushka (33) and the equivalence in Moksha kovt'i-lovt'i (see endnote 17) demonstrate. The point in this kind of examples, nevertheless, is not the variation between local dialects. Rather, it illustrates how language and especially rhyme and the number of syllables are used to emphasize the thematic contrasts.

Although chastushkas are newcomers in Erzya folklore tradition they are still carried by the same oral basis as the old genres were based on. In western world serial films and comics they respond to the same human needs as fairy tales did in earlier times. In this sense, the chastushkas obviously profit from their impulsive and momentaneous structure and thematic aptness to react on every-day matters. They are current and can therefore spread pretty fast from mouth to mouth like rumors and gossip do, although the latter have a strong tendency to die out when it loses its pertinence not to forget the importance of the audience (cf. Virtanen 1980: 141-145). With respect to this kind of oral tradition chastushkas, however, have another structural feature that supports their maintenance, namely rhythm and melody. Melody does not seem to bear a very important role, because individual chastushkas frequently do not have their own melodies, whereas rhythm and metrics are more decisive for the structure of the chastushka and the selection of words.

Samoshkin (1976: 57) notes that in certain Mordvin-Russian parallel chastushkas Russian phrases and entire verses are included in the Mordvin version and the rhythm between the Mordvin and Russian version is identical.

From a metrical viewpoint, Erzya chastushkas consistently display the trochee, a two-syllable metric foot. The most typical verse structure of the sample below is $\mathrm{A}-\mathrm{B}-\mathrm{A}-\mathrm{B}$, in which the syllable number of the first and third line, respectively the second and fourth line correspond to one another. The number of syllables in this type of chastushkas is $8-7-8-7$ and it occurs in 23 chastushkas of the presented data. The hyme pair is more frequently formed between the second and fourth line than the first and third, which, nevertheless, is also possible. An illustrative example is seen in chastushka 6 (example [1]) that has the same metrical structure in variants (chastushkas 12 and 30) presented by other informants and published collections as well (see endnote 3).
(1) il'a jaka umaŕ sadga
$+\mathrm{o}+\mathrm{o}+\mathrm{o}+\mathrm{o}$
il'a jaka rosava
$+\mathrm{o}+\mathrm{o}+\mathrm{o}+$
il'a manči l'ija t'ejt'er
$+\mathrm{o}+\mathrm{O}+\mathrm{O}+\mathrm{O}$
il'a t'ejne dosada
$+\mathrm{o}+\mathrm{o}+\mathrm{o}+$ 
'Don't walk through apple orchards, don't walk through the dew, don't entice another girl, don't do any harm.'
not.IMP walk apple garden.PROL

not.IMP walk dew.PROL

not.IMP entice other girl

not.IMP do.FREQ harm

Erzya is a morphologically complex language with a rich suffixal system. Grammatical elements are frequently used to constitute rhyme pair chastushkas. This is illustrated in the relationship between the prolative form rosava 'dew.PRoL' and dosada 'harm' in example (1), and example (2) that displays rhyme pairs between two definite forms l'iśmaprás' 'spring.DEF' and alužoś 'darling.DEF' and by repeating the negative particle araś.
(2) t'e kodamo l'iśmapŕaś $+\mathrm{o}+\mathrm{o}+\mathrm{o}+$ čuvan, čuvan, ved'araś $+\mathrm{o}+\mathrm{o}+\mathrm{o}+$ t'e kodamo moń alužoś $\quad+0+0+0+0$ učan, učan, son araś $\quad+0+0+0+$

What is this spring like, this what.sort.of spring.DEF I dig and dig there is no water, dig.1 SG dig.1SG water not what is my darling like, this what.sort.of my darling.DEF

I wait and wait, (s)he won't come. wait.1SG wait.1sG (s)he not

The chastushkas display consistently the trochee, although the metric pattern is often elliptic as in the first line of example (2). Most frequently the variation from the prevailing syllable structure $8-7-8-7$ is seen in the lack of one syllable. Thus the first or third line may consist of seven syllables instead of eight and the second respectively fourth line may have six syllables. These deviations increase the number of possible combinations considerably. As a rule, the latter part (AB) of the couplet of two lines may not have more syllables than the first one. In other words there is an implication that the lines two and four must not be longer than the preceding line. There are only few exceptions to this rule in the following data. Chastushka (49) is the only one in which the latter line of a couplet is longer than the first one. In addition to it chastushka (55) provides with another exception in which the second line is longer than the first one and in chastushkas $(1,3$, and 50$)$ the third line is shorter than the fourth one.

\section{The collecting and organizing of the data}

The data are organized according to informants who presented them, but they have not been sorted on the basis of any other criteria such as thematic or metric structure. The 58 chastushkas were collected directly from nine informants, of which eight were women. Many of the chastushkas have parallel versions repeating the same motives or lines in published sources. These variants are presented in numerated endnotes that follow the chastushkas. There is also mutual similarity between many of the col- 
lected chastushkas. The thematic and structural correspondence between individual songs is mentioned by referring to parallel variants after those chastushkas that have in common with others. The texts are transcribed by applying as simple principles as possible. PhD Ol'ga Yerina has been of dispensable help in checking and correcting the transliterations. She has also taken the trouble to search for the parallel versions of the recorded data in published sources.

\section{References}

Honko, Lauri 1980: The lament. Problems of genre, structure and reproduction. - Lauri Honko \& Vilmos Voigt (eds.), Genre, Structure and Reproduction in Oral Literature. Budapest: Akadémiai Kiadó. 21-40.

Hoppál, Mihály 1980: Genre and context in narrative event. Approaches to verbal semiotics. - Lauri Honko \& Vilmos Voigt (eds.), Genre, Structure and Reproduction in Oral Literature. Budapest: Akadémiai Kiadó. 107-128.

Kukk, Tiit 1989: Vesjegonskin karjalaisten tšastuškoja. Castrenianumin toimitteita 32. Helsinki.

Lallukka, Seppo 1990: The East Finnic Minorities in the Soviet Union. An Appraisal of the Erosive Trends. Annales Academiae Scientiarum Fennicæ B 252. Helsinki: Academia Scientiarum Fennica.

Lehtipuro, Outi 1980: Perinteentutkimus tienhaarassa. - Outi Lehtipuro (ed.), Perinteentutkimuksen perusteita. Porvoo - Helsinki: WSOY. 7-18.

MECh = Мокшэрзянь частушкат. Саранск: Мордовское книжное издательство 1962.

MNP = Мордовские народные песни. Саранск: Мордовское книжное издательство 1969.

Mordwinische Volksdichtung = Mordwinische Volksdichtung I-VIII. Mémoires de la Société Finno-Ougrienne 77, 81, 84, 91, 161, 162, 176, 178. Helsinki: Finno-Ugrian Society 1938-1981.

PMNMI = Памятник мордовского народного музыкалного искусство I-III. Под редакцией Е. В. Гиппиуса, составитель Н. И. Бояркин. Саранск: Мордовское книжное издательство 1981-1988.

Saarinen, Sirkka 1990: Suomalais-ugrilaisten kansojen folklore. Turun yliopiston suomalaisen ja yleisen kielitieteen laitoksen julkaisuja 36. Turku: Turun yliopisto.

Samoshkin 1965 = Самошкин, А. Г.: О всаимосвязах между русской и мордовской частушкой. - Этногенез мордовского народа. Под общей редакцией Б. А. Рыбакова и.т.д. Саранск: Мордовское книжное издательство. 402-407.

Samoshkin 1976 = Самошкин, А. Г.: Песни ходят по селеньям. Саранск: Мордовское книжное издательство.

$\mathrm{SM}=$ Сиде моронят. Отв. ред. А. Н. Келинась. Саранск 1992.

UPTMN = Устно-поэтическое творчество мордовского народа I-XII. Саранск 19632003.

Vasmer \& Trubachev 1964-1973 = Фасмер, М.: Этимологический словарь русского языка 1-4. Перевод с немецкого и дополнения О. Н. Трубачева. Москва: Издательство Прогресс.

Virtanen, Leea 1980: Perinteen yhteisöllisyys. - Outi Lehtipuro (toim.), Perinteentutkimuksen perusteita. Porvoo - Helsinki: WSOY. 133-181. 


\section{Erzya chastushkas}

The documentation and recording of the chastushkas took place during field work expeditions in 1991 and 1995 in the Republic of Mordovia in Russia (Respublika Mordovskaya). One of the informants was born outside of the Republic (Orenburgskaya Oblast), whereas all the others were born and living in the Republic of Mordovia. The documentation of the is the following: chastushkas (1-3) Moksholey village, Chamzinskiy District; chastushkas (4-7) Kuzim village, Bol'shebereznikovskiy District; chastushkas (8-10, 40-57) Erzyan' Nayman (in Russian St. Naymany) village, Bol'shebereznikovskiy District; chastushkas (11-17) Kosogor village, Bol'shebereznikovskiy District; chastushkas (18-30) Vere Kuzla (in Russian Verkhniy Kuzla), Orenburgskaya Oblast; chastushkas (31-39) Kuchan' vel'e (in Russian Kuchenyayevo), Ardatovskiy District; chastushka (58) Atyashevo, Atyashevskiy District.

The texts were transliterated, analyzed and translated together with Dr. Ol'ga Yerina, a native Erzya speaker who also compared the data with published sources.

(1) mon a mol'an pel'eveńe bańav orožijamo vana siń [jakit'] klubov Jelćiń jalgań kočkamo ${ }^{1}$

(2) dajt'e jalgat t'eke veŕga moronok kajasinek valske rana miń st'atano vid'imanok pradsinek ${ }^{2}$

(3) užo jalgat, meźe jovtan teči koda mon śiźiń surkinasto klubov kišt'eme moramo siń

(4) tšastuškat'ńeń morasińek garmonija ikel'e vajgel'eńek targasinek t'e publikant' ikel'e

(5) mon a mol'an pel'eveńe bańav orožijama lučše mol'an čoksńa klubov vansa pingiś kodama
I do not go at midnight, to the sauna in order to do magic.

Over there they [are visiting] the club to elect comrade Yeltsin.

[Cf. 1, 5, 22, 40.]

Friends, this way up here, let us cast our song. Early in the morning we shall rise and finish our sowing.

Wait friends, I'll tell you something. Today how I got tired, I came from Surkina to the club, to dance and sing.

Let us sing these chastushkas before the accordion, let us present our voices before this public.

I do not go at midnight, to the sauna in order to do magic. I prefer to go to the club in the evening and see what the era looks like.

[Cf. 1, 5, 22, 40.] 
(6) il'a jaka umaŕ sadga il'a jaka rosava il'a manči l'ija t'ejt'er il'a t'ejnée dosada ${ }^{3}$

(7) val'ma langsa t'uža katka viš(i)ńe l'evkske marta mon mil'onam kadimim viš(i)ńe ejkakške marta

(8) karman tšastuškań morama eśeń erźań kelńese konstitucijado jovtńit' érvaj viška velńese

(9) oj dojarka maja mańa dajka vejce kišst'ana mińek arast' aližińek kid'ejak a vizdt'ana

(10) morak mazika, morak balalaikaś tonćet' koda karmat urvakstomo sajimak $i$ mon $^{5}$

(11) val'malińe kasi kil'ej reproduktor alinzi radio veld'e maŕavit' Gorbačovoń valonza

(12) il'a jaka sad piŕeva il'a tapa rosadat il'a manče lijań ćorat il'a t'ejnée dosadat

(13) dojarkanok pek robotit' lamo lovco pot'avtit' valcke rana sin tujit' čoksńa pozda sin mad'it'
Don't walk through apple orchards, don't walk before the dew, don't entice another girl, don't do any harm. [Cf. 6, 12, 30.]

At the window a brown cat with a small kitten, my darling left me with a small child.

I'm going to sing some chastushkas in my very own Erzya language, they are telling about the constitution in every single little village. [Cf. 8, 15.] $]^{4}$

Oh, milker, my Manya, let's dance together, we don't have a darling, we are not ashamed of anybody.

Sing beauty, sing, the balalaika is yours. When you are going to marry, take me as well.

(Right) under the window there is a birch growing, with a loudspeaker under it, over the radio are heard the words of Gorbachev. [Cf. 11, 15.]

Don't walk through the garden, don't tramp on the seedlings, don't entice someone else's boyfriend, don't do any harm.

[Cf. 6, 12, 30.]

Our milkers are working hard, they are milking a lot of milk, they leave early in the morning, they lie down to sleep late in the evening. 
(14) ojna škańe miń jal'gińek lamo nuža ńejińek a ńej vadŕa eŕamonok ved'eks čud'i t'evenéek

(15) val'malonok kasi kil'ej kudrasonzo sornotńe komsomolkaś mazi Nina konstitucijańt' jovt'n' $i^{6}$

(16) moń mil'kinem Samaŕca di jaki šolkoń panarca a moń éran vel'ese di jupkam śiśem kel'ese ${ }^{7}$

(17) veŕga l'ivt'i eroplan l'očik rangi, kundatan moń alužiś armijaso śorma kuči, a kadtan

(18) verga l'ivt'i jeroplan udalonzo lačo perestrojkańt' a t'ejsinek kulotano vačo ${ }^{8}$

(19) vasńa kuźan kovont'e mejl'e valgan lovont'e źardo večkemam kadsamam mol'an prokuroront' $e^{9}$

(20) vaj kodamo viŕeś mazi vaj kodamo čiś l'embe vaj jalginem bal'aginem l'istt'a martom kišt'eme

(21) alopeste veŕepev čavo boćka keveri erva nolgov odćorant'e mazi t'ejt'eŕ éravi ${ }^{10}$
During the war, friends, we saw a lot of poverty. But now our life is nice, our things are flowing like water.

There is a birch growing out our window, she's ruffling her curls, the Komsomol worker beautiful Nina is telling about the constitution. [Cf. 8, 15.]

My darling is in Samara and wears a silk shirt, but I live in a village, I have a skirt of seven spans.

Above there is an aeroplane flying, the pilot yells, I'll catch you, my darling is in the army, sending letters, I won't leave you. [Cf. 17, 18, 27, 43, 44.]

Above there is an aeroplane flying, with a wedge behind it, we are not going to build perestroika, we are going to starve to death.

[Cf. 17, 18, 27, 43, 44.]

At first I shall climb to the moon, afterwards I shall descend to the snow, when my darling leaves me, I shall go to the prosecutor. [Cf. 19, 33.]

Oh, how the forest is beautiful, oh, how warm a day it is, oh my darling my coltsfoot, come and dance with me. [Cf. 20, 41, 46.]

From the lower end to the upper end, an empty barrel is rolling, a beautiful girl is needed for every snot-nosed young man. [Cf. 21, 42.] 
(22) mon a mol'an t'eči pakśav kukuruzoń kočkomo a mol'an mon promks kudov mazi moroń moramo

(23) val'ma langso ašt'i ćeća ćvet'i rozovojste mon večkemam tuś lijańeń a mon goŕovojste

(24) val'ma langso pivt'eń lovso a stol langso čapamo mon večkemam tuś kišt'eme mon mel'gando ćapamo ${ }^{11}$

(25) avam ramaś bot'inkat piže šnurka marto mon a karman baśamo ńe vaćetńeń marto

(26) śiśem ćorat pando prasto uskit' papant' poŕadkasto siśem t'ejt'ert' avard'it' kov siń papant' keverd'it'

(27) verga l'ivt'i jeroplan a lapando nill'e orgot t'este busurman tatar kel'ej pil'e

(28) mil'kam žalka, mil'kam žalka końazondo tumoń palka nérezende kolija il'azo večke l'ija ${ }^{12}$

(29) pando pŕaso samovar pando alo čajńik mińek Al'o melníćaso vatrakšoń načal'ńik ${ }^{13}$
Today I'm not going to the field to weed the corn, but I'm going to the meeting house to sing some beautiful songs. [Cf. 1, 5, 22, 40.]

There is a flower on the window ledge, blossoming like a rose, my darling went to another, but I [went] mourning.

On the window ledge there's churning milk,

but on the table sour, my darling went to dance, I went after him/her to clap (rhythm) for him/her.

My mother bought shoes with green laces, I am not going to talk with those shit piles.

Seven men up on the hill are hauling the penis out the lane, seven girls are crying, where are they rolling the penis to?

Above there is an aeroplane flying, but it has four wings, get out of here, Busurman, Tatar with wide ears! [Cf. 17, 18, 27, 43, 44.]

I feel sorry for my darling, I feel sorry for my darling, who gets an oak stick for his forehead, a block in his/her snout, he/she mustn't love another one.

A samovar on the top of a hill, a tea boiler at the foot of the hill, our Alyosha is at the mill the boss of a frog. 
(30) il'a jaka jalgaj mel'gan il'a tapa rozada jalat'eke a večksamak anśak t'ejat dosada

(31) kišt'emejak maštan moramojak maštan kolhozoso robotamo ovśejak a maštan ${ }^{14}$

(32) t'e kodamo l'iśmapŕaś čuvan, čuvan, ved' araś t'e kodamo moń alužoś učan, učan, son araś ${ }^{15}$

(33) verey vačtan koyst'eń aloy vačtan loyst'eń moń al'užom kadimem mol'am prokurorśt'en' ${ }^{16}$

(34) ćigan-avaś oružijeś ašo ponan kovtaso moń al'užom araś t'ese aźd'o t'enze jovtado

(35) Kosogor vel'eś pokš no araś kul'turazo sodon bańa udalga aśči molod'ožozo ${ }^{17}$

(36) mon večkil'in Kol'a l'em a ńey Kol'a kadimem Kol'an eśenze ikel'e vejke ava šaldimem

(37) Kol'a śed'ak, Kol'a śed'ak Kol'a il'a nuźal'do čokšne alužot kevkst'ińek karmavtinźet' śed'amo ${ }^{18}$
Don't walk, my friend, after me, don't tread on the seedlings, you don't love me anyway, you are just doing harm. [Cf. 6, 12, 30.]

I can dance, I can sing, working at the collective farm is something I can't do at all.

What is this spring like, I dig and dig there is no water, what is my darling like, I wait and wait, he/she is not there [= doesn't come $]$.

I look up to the moon, I look down to the snow, my darling has left me, I'm going to the prosecutor. [Cf. 19, 33.]

The gypsy lady did magic, in a white wool coat, my darling is not here, go and tell him/her.

Kosogor village is big, but it doesn't have any culture, behind a sooty sauna, is located its youth.

I used to love the name Kolya [Nikolay], but now Kolya has left me, in front of Kolya himself, a lady mocked me.

Play, Kolya [Nikolay], play, Kolya, Kolya don't be lazy, in the evening we asked your darling, she made you play. 
(38) ul'evel' hot' ul'evel' paro ćora ul'evel' a iśt'amo pianićaś proval'ića tujivil'

(39) kučań vel'en t'ejt'ertńe veśe jakit šolkso ombo vel'eń ćoratne mel'gast' panćit polkso

(40) vaj a mol'an pel'e veń bańav orožijama lučše mol'an čoksńa klubov pastanovkań vanoma ${ }^{19}$

(41) vaj kodama viŕeś piže vaj, kodama, čiś l'embe moń jalginem bal'aginem ad'a martom kišt'ime

(42) vere peste alo pev tašto boćkat keŕavit' [keverit'] kažne nolgov ćoraneń vadŕa t'ejt'eŕ éravi ${ }^{20}$

(43) verga l'ivt'i ve galine eź t'enze jalga vešńi kodamo načal'nik putat[ano] eś t'enze źepe pešt'i

(44) verga l'ivt'i jeroplan kunškasonzo pružina kona večki robotama mad'i apak užina $^{21}$
If there were, if there were a good guy, but this kind of drunkard should leave through the earth.

The girls of Kuchan' village, they all wear silk, the boys of the next village are chasing after them in droves.

I do not go to the midnight, sauna in order to do magic. I prefer to go to the club in the evening to see the play.

[Cf. 1, 5, 22, 40.]

Oh, how the forest is green, oh, how the sun is warm, my friend, my coltsfoot, come and dance with me. [Cf. 20, 41, 46.]

From the upper end [of the village] to the lower end, the old barrels are rolling, for every snot-nosed guy, a beautiful girl is needed. [Cf. 21, 42.]

Above there is a goose flying, looking for a mate, what sort of a boss we shall (ever) put, he will fill his own pocket. [Cf. 17, 18, 27, 43, 44.]

Above there is an aeroplane flying, with a spring in the middle of it, he/she who likes to work, goes to sleep without having a dinner. [Cf. 17, 18, 27, 43, 44.] 
(45) karman jalgine kišt'ime kavto pil'gim vačkod'iń eźiń dumajak mon koda sirečit'i pačkod'iń

(46) viŕ ćirese kasi ćećka ked'em venst'sa mon śeźsa oh jalgine, bal'aginem sirečińt' ńej kov t'ejśan

(47) miń mird'em marto ašt'inik čoksńeś ulńeś kel'me a ńej nargi langozim paraźiteń śel'me

(48) prasam paća seńala čin karšo a olavća mon aližim śeste vadŕa kij langsak a polavtsa

(49) Moskovoń zooparkt'nese kl'etkaso ašt'it pavat'ne minek vel'eseńek lama pianića avat'ne

(50) mińek araś muškinik araś minek vata Gorbačov i Jeltsin narodońt' kadiź štapa

(51) perestrojkaś koda karmaj dumiń, vadŕa éramo a ńej uźert, pilat sajan tujan viren keŕama

(52) ona tosa vireńt' jona traktort moda vel'avtit' uborkasto mašinaso šuron't' kudov ujevt'it'
I'm going to dance, my friend, I stamped my two feet, I didn't think, how I arrived to old age.

There is a flower growing on the edge of the forest,

I stretch my hand and pick it, oh my darling my coltfoot, where am I going to put the old age, now? [Cf. 20, 41, 46.]

We were sitting together my husband and I, the evening was cold, but now that eye of a parasite he's teasing me. ${ }^{22}$

The scarf on my head is bluish, it doesn't turn pale in the sun, my darling is the most beautiful, I won't change him/her for anyone.

In the zoos of Moscow the peacocks are in the coop, in our village, there are many drunkard ladies.

We don't have tow, we don't have cotton, Gorbachev and Yeltsin, left the people naked. [Cf. 50, 57.]

When perestroika began, I thought life would be nice, but now I take my axe and saw, I am going to cut down the forest.

Over there towards the forest, the tractors are turning the soil, at harvest time they'll use trucks, to sneak the grain home. [Cf. 52, 56.] 
(53) viŕ čirise kasi tumo prazo mastorov komaś pando pŕaso pužeń ćećkaks iśt'a jutaś od poraś

(54) mol'an mol'an lejeń krajga kajan ćećka ved'et'eń kostojak mezd' a mujan lakića śed'ejent'eń

(55) vanidi meńil'int' koda peltńe sin ujit' veśe vel'ent' od lomatne veśe gorodov tujit'

(56) ona toso vireńt' alo traktor moda vel'avti mon aližiś iskrasinzi di anśak pranzo čaravti

(57) Gorbačov i Jeltsin meźe t'eve t'eid'e Rossijaso źaro narodt vačo peke kadid'e

(58) aida Vanja bazarov eh ramatano pomila šl'atanok, nardatanok śed'e mazit' ult'anok
Near the forest an oak is growing, with its top bent to the ground, like a faded flower on a hill top, their youth passed on.

I walk and walk along the riverside, I throw a flower in the water, where shall I find something for a bursting heart.

Look at the sky, how the clouds fly, all young people of the whole village, they are all leaving to the town.

Over there by the forest, a tractor is turning the soil, my darling is in his Iskra (tractor), and only shakes his head. [Cf. 56, 61.]

Gorbachev and Yeltsin, what sort of work did you do, how many people in Russia, you have left starving! [Cf. 50, 57.]

Let's go Vanya [Ivan] to the market, oh, let's buy a whisk, we (shall) wash, we (shall) wipe, we shall be more beautiful. 


\section{Comments}

1 On the 12 June 1991 the first free presidential elections were organized in Russia. Boris N. Yeltsin achieved an indisputable majority in the first round and was elected the first president of Russia. The third line is elliptic and the informant obviously noticed that a simple predicate as jakit' [walk.3PL] 'they go' that would semantically fill the gap does not metrically match to the 8 -syllable pattern of the first line.

2 davaj, jalgaj, śed'e veŕga

moronok targasinek

valske ranajak st'atano

di normanok pradsinek

(UPTMN 5: 175)

There are considerable similarities between the two variants in each line and the main difference is found in the word choice such as kajasinek 'let us throw (it)' (example 2) instead of targasinek 'let us pull (it)', vid'imanok 'our sowing' (example 2) instead of (dy) normanok 'our quota'. The introduction dajt'e jalgat 'let us, friends' addresses a plural (example 2) instead of davaj, jalgaj 'let us, friend' that addresses a singular. Despite the lexical changes the number of syllables and the metrics of the chastushka remain the same.

$3 \quad$ il'a jaka mon piŕeva

il'a tapa rosadat

il'a panśe mazi mel'ga

il'a t'ejné dosadat

(UPTMN 5: 230)

il'a jaka virga-sadga

il'a tapa rosada

il'a večke moń alužam

il'a t'eje dosada

(UPTMN 5: 231)

There is ample of variation in different versions of examples $(6,12,30)$, and those published in UPTMN 5. In other versions than example (30) the chastushka consists of four imperative negations beginning with the auxiliary verb il'a 'do not (2sG)'. Furthermore the chastushkas, except of example (30), bridge two thematic and mutually metaphoric sections, of which the first one is a garden (orchard, seedling) that one is not supposed to enter, the second one of an animate beloved maid or youngster that another one is not supposed to entice. The first one is manifested as umar sad 'apple orchard' in example (6), two synonyms sad (< Russian sad id.) and pire 
'garden' in example (12), the latter one in (UPTMN 5: 230), and finally as viŕ-sad 'forest-garden' in (UPTMN 5: 231). The protected target of love is manifested as t'ejt'ér 'girl' in example (6), ćora 'boy' in example (12), mazi 'beautiful' and aluža 'friend; beloved' in (UPTMN 5: 230-231).

4 karman častuškań moramo

eśeń erźań kelńese

partijań programmant' lovnit'

mińek éva vel'ese

(UPTMN 5: 168)

śed'ak, śed'ak garmonija

nil'e-vet'e kelnese

konstitucijant' lovnit'

erva viška vel'ese

(UPTMN 5: 234)

In comparison to the two parallel versions published in UPTMN example (8) seems to combine two distinct motives. Yet, this is an inherent characteristic of chastushkas as part of oral poetry. Metrically, the informant keeps the balance between the first and third line both consisting of eight syllables as a contrast to the second and fourth line consisting of seven syllables each. Consequently, the partitive (ablative) case is used as the case of object in konstitucijado in example (8) instead of konstitucijant' as in (UPTMN 5: 234).

5 This particular chastushka was first presented in Russian, but after some requests the informant performed it in Erzya. Nevertheless, the informant claimed that usually chastushkas do not have parallel variants but are sung separately in Russian and Erzya and have different themes.

śed'ak, Kol'a veśolasto

garmoškińeś tonśet'

koda karmat urvakstamo

sajmaka monseń

(UPTMN 5: 196)

garmonist moraka

garmonijaś tonceń

dumandat ŕvjajama

ŕvaks śavamak monceń

(MECh 27) 
Unlike most other chastushkas presented in the current paper, example (10) does not pretend to keep a strict number of syllables, but allows a very free metric formula in each line. In the variants published in chastushka collections the rhythm and usual correspondence between lines 1 and 3 respectively 2 and 4 holds without deviation.

6 sadso kasi umarina

kudŕasonzo sornovtńi

mazi t'ejt'é, paro Nina

od programmant' ńej jovtńi

(UPTMN 5: 168)

sadso kasi umarina

lopasonzo sornovtńi

komsomolka minek Lena

konstitucijant' jovtńi

(UPTMN 5: 234)

As in example (8), the same informant appears to combine themes in example (15), because the chastushka shares parts of two variants published in UPTMN. In this case, the thematic variation is based on the structural compatibility between lines 1 and 3 that consist of eight syllables in example (15) in contrast to the seven-syllable lines 2 and 4.

7 mon alužam Moskov ošso

mon žo éran vel'ese

cikordića kemt' moń pil'gse

jupkam koto kel'ese

(MECh 27)

The similarity between example (16) and the text published in MECh consists of a metric identity and the structure $\mathrm{ABAB}$ between the lines. Thematically the subject of the text locates herself in a village (vel'ese), whereas her beloved is in a distant city (Moscow, Samara). The span (koto 'six' or śiśem 'seven') of the skirt is contrasted with the silk shirt in example (16). This chastushka has a parallel in Moksha in which these three elements are present as well:

zal'omaźe Moskusa

jakaj śeraj kost'umsa

a mon t'äsa, vel'esa

jakan nil'e kemsa

(SM 101) 
8 The informant reported that he had learned this chastushka in Saransk (the capital of the Republic of Mordovia), although he himself was born and had lived in the Orenburgskaya Oblast further in the east. According to the informant, the majority of data recorded from him originates from the Orenburgskaya Oblast.

9 The informant said that he knew this chastushka from both Saransk and the Orenburgskaya Oblast.

10 vere peste alopev

čavo boćka keveri

sonś berakške ćorinéś

vadŕa t'ejt'ér éravi

(UPTMN 5: 186)

This chastushka is based on two semantic contrasts: an empty bottle rolling down from the upper end to the lower end (in example [22] vice versa [!]), in the Moksha example (SM 57) below from the new end to the old end, and the miserable youngster longing for a beautiful girl. In example (22) the informant breaks the metric balance whereas in example (42) all lines consist of seven syllables.

od pesta sire pev

šava boćkat kevorgdiht'

kažnaj nolgu st'irt'i

mazi ćorat éraviht'

(SM 57)

verd'e pesta alda pet'i

boćkańätńe kevoriht'

piče vel'ent' st'irnätńänd'i

mazi plat'jat eraviht'

(SM 97)

pinkedsta keratav

šava boćka kevori

kažnaj kal'd'av ćorat'i

ćebär st'irńe éravi

(SM 112)

11 val'ma langso pivt'i lovso

a stol langso čapamo

mon alužam tuś kišt'eme

mon mel'ganzo ćapamo

(UPTMN 5: 189) 
The chastushka recorded from the informant is almost identical with that published in UPTMN 5. The number of syllables is identical and the most considerable change besides introducing the dialectal mel'gando in example (24) is the conversion of the gender of the beloved (alužam in UPTMN) from masculine to feminine (večkemam in example [24]).

12 The following couplet (Orenburgskaya Oblast) of the same informant resembles the chastushkas and consists of four lines, thematic turnovers and is based on rhymes and rhythm. The informant presented it as a children's song.
dur-dur-durso
Woarr-woarr-woarr,
jakin mel'gat nurco
araśel'it' kudoso
I followed you in a sleigh,
ćurśén ponksot tuloso you were not at home,
I put dibs on your trousers with a peg.

13 pando pŕaso samovar

a pandalo čajnik

moń alužam Moskovso

toso son načal'nik

(UPTMN 5: 200)

pando pŕaso samovar

pando alo čajnik

meźe jalgat vantado

Fed'ajak načal'nik

(UPTMN 5: 235)

The two first lines of example (29) and the two variants published in UPTMN are identical and the variation of the two latter lines is based on keeping the rhyme čajnik - načal'nik unchanged.
kišt'emejak maštat
moramojak maštat
a kolhozoń robotant'
ovto ladso šaštat

(UPTMN 5: 181)

There is only little variation between the Erzya (example [31], UPTMN) and Moksha variants (SM 134; see below). In the version published in UPTMN the subject of the text addresses to a second person singular whereas in the two other ones the subject is in the first person singular. In example (31) the informant applies the possibility to an unexpected thematic change characteristic of chastushkas by applying a humoristic lexical change ovśejak 'at all' instead of ovto ladso 'like a bear'. 
kišst'imonga maštan

moramonga maštan

kak robotama karman

koda ofta ̌̌aštan

(SM 134)

15 t'e kodamo liśmaprás?

čuviń, čuviń ved' araś

vaj, kodamo t'e ćoraś?

učiń, učiń son araś

(UPTMN 5: 220)

16 verev varštan kovont'eń

alov varštan lovont'eń

buti alužom kadsamam

mol'an prokuroront'eń

(UPTMN 5: 183)

Example (33) is almost identical with (UPTMN 5: 183) that both like example (19) and the Moksha example below display the rhyme and spatial distinction between $k o v$ 'moon' (up) vs. lov 'snow' (down). In example (19) and UPTMN the subject threatens to prosecute his/her beloved, if (źardo 'when', buti 'if') (s)he is left alone whereas in example (33) the subject uses the past tense and emphasises that this has already taken place and, consequently, the subject will go to the prosecutor's. In the Moksha version the action is connected with being touched (tokasamań) instead of being left.
väri vanan kovt'i
alu vanan lovt'i
kodak kije tokasamań
tujan prokurort'i

(SM 27)

17 The theme Kosogor is associated with place where it was recorded, but not with where the singer comes from.

18 Kol'a śed'ak, Kol'a śed'ak

Kol'a il'a nuźaldo

čokšńe alužot kevkst'ije

tońet' meŕi śed'amdo

(UPTMN 5: 197)

There is only minor structural difference between example (37) and the version published in (UPTMN 5: 197), while the semantic actors of the two variants are identical. 
In example (36) the subject uses a plural form (kevkst'inek 'we asked') instead of singular and a more analytic verb construction karmavtinźet 'he made you (do something)' instead a narrative reference tońet' meŕi in UPTMN.

19
mon a mol'an pel'eveńe
bańav orožijamo
lučše mol'an čoksńe klubov
vadŕa p'esań vanomo

(UPTMN 5: 233)

The introduction of this chastushka and the two first lines are recorded from many informants. The beginning of the chastushka is based on a negation mon a mol'an 'I am not going to go' that suggests that another alternative will be presented. The variation between examples $(1,6,22,40)$ and (UPTMN 5: 233) is seen in the two latter lines that reveal the semantic culmination of the chastushka. In all cases the point of the text is revealed on the last line that shows similarity only between example (40) and (UPTMN 5: 233).

20 The correct form instead of keravit' (a reflexive derivation of kerams 'cut, chop, hew' etc.) should be keverit' (cf. examples [22] and [42]). The translation is based on the semantics of the corrected version.

\section{1 verga l'ivt'i joroplan \\ udalonzo pružina \\ ki kolhozso a roboti \\ mad'i apak užina \\ (UPTMN 5: 174)}

22 In fact, the fourth line of the translation corresponds to the third line of the text, and the third line (the eye of a parasite) of the translation corresponds to the fourth line of the text.

Riho Grünthal<riho.grunthal@helsinki.fi >

Department of Finno-Ugrian Studies

P.O. Box 25

FI-00014 University of Helsinki 